\title{
Analisis Evaluatif Manajemen Pemasaran pada Jenang Dodol Teguh Raharjo Ponorogo Perspektif Balanced Scorecard"
}

\author{
Okta Khusna Aisi, M.Pd.I \\ Institut Agama Islam Riyadlotul Mujahidin (IAIRM) Ngabar Ponorogo \\ oktaaisi@gmail.com
}

\begin{abstract}
Along with the rapid development of science and technology, the entrepreneurs are required to always do learning and evaluation in order to be able to survive facing competition. Before the balanced scorecard was discovered, companies generally would use the traditional approach of using separate measrement tools such as finance because only the finance parts were easily measured, calculated and analyzed. Throught the balanced scorecard, all company activities can be measured, analyzed, and evaluated in an integrated manner quickly and easily. Balanced scorecard is a tool used to measure company performance by paying attention to financial and non financial concepts between the short term and the long term and involves internal external factors.
\end{abstract}

Keywords: Marketing Management, Balanced Scorecard System

Abstrak

Seiring dengan pesatnya perkembangan ilmu pengetahuan dan teknologi, para pengusaha dituntut untuk selalu melakukan pembelajaran dan evaluasi agar bisabertahan menghadapi persaingan.

Sebelum penilaian dengan Balance Scorecard ditemukan, perusahaan umumnya akan menggunakan pendekatan tradisional menggunakan alat pengukur yang terpisah seperti keuangan karena hanya bagian keuangan yang mudah diukur, dihitung dan dianalisis. Pemikiran yang seimbang dengan Scorecard. Semua kegiatan perusahaan dapat diukur, dianalisis, dan dievaluasi secara terintegrasi dengan cepat dan mudah. Balanced Scorecard adalah alat yang digunakan untuk mengukur kinerja perusahaan dengan memperhatikan konsep keuangan dan non keuangan antara jangka pendek dan jangka panjang dan melibatkan faktor eksternal internal.

\section{A. Pendahuluan}

Industri makanan dan kuliner semakin berkembang di kota Ponorogo. Berkembangnya usaha oleh-oleh khas daerah di Ponorogo sebagai sebuah industri kuliner dan pasar yang menjanjikan, menyebabkan perusahaan atau produsen oleh-oleh mengembangkan berbagai macam jenis produk oleh-oleh. Banyaknya produsen makanan oleh-oleh menyebabkan suatu perusahaan harus mengembangkan berbagai strategi pemasaran untuk menarik minat konsumen dan menghadapi persaingan pasar dengan produsen yang lainnya. Hal ini juga menjadi suatu permasalahan yang serius bagi produsen jenang dodol Teguh Raharjo sebagai salah satu produsen home industry makanan oleh-oleh khas Ponorogo.

Sebagai perusahaan yang bergerak di bidang usaha oleh-oleh, Jenang Dodol Teguh Raharjo yang terletak di Jl. Wibisono No. 90, Keluraham Kepatihan, Ponorogo telah membuktikan kemampuannya bertahan dalam persaingan pasar. Terbukti dengan segala usahanya, yang dirintis sejak tahun 1982 sampai sekarang jenang dodol Teguh Raharjo menjadi salah satu pusat toko oleholeh Ponorogo yang banyak diminati dari semua lapisan masyarakat. Cita rasanya yang legendaris menjadi daya tarik bagi konsumen untuk tetap memilih jenang Teguh Raharjo sebagai konsumsi sendiri atau sebagai buah tangan yang tidak diragukan lagi kualitasnya. Perusahaan jenang ini sudah menjadi primadona warga Ponorogo kualitasnya yang unggul sudah melekat dibenak konsumen. Serta dapat terus berkompetisi dan bergerak searah dengan keinginan konsumen, karena pada 
dasarnya fungsi perusahaan adalah memproduksi barang dan jasa yang dapat diterima konsumen sekaligus dapat memenuhi keinginan konsumen.

Seorang wirausahawan harus mengetahui dan memahami bahwa pemasaran merupakan kegiatan yang amat penting dalam menjalankan usaha, baik usaha besar maupun usaha kecil. Saat ini, wirausahawan harus fokus pada konsumen, yaitu mengusahakan agar pelanggan tetap berhubungan dengan kita.

Dalam persaingan yang sangat ketat sekarang ini, wirausahawan harus mampu mempertahankan, bahkan meningkatkan kepercayaan konsumen pada produk atau jasanya. Untuk memelihara kesetiaan konsumen, tentu saja dilakukan dengan memberi kepuasan kepada mereka melalui nilai lebih yang diterimanya dibanding dengan uang yang dia keluarkan untuk memperoleh suatu barang. ${ }^{1}$

Dalam berbisnis, setiap orang akan berhubungan dengan pihak-pihak lain yang juga pebisnis dan pesaing besar. Seorang pebisnis akan selalu berusaha memberikan pelayanan yang terbaik (prima) kepada mitra bisnisnya. Pelayanan terbaik (prima) tentunya tidak bertentangan dengan prinsip syari'ah (Islam), seperti suap, menipu, serta praktik-praktik bisnis yang tidak bermoral. Rasulullah SAW, pun tidak pernah berusaha menghancurkan kepercayaan itu juga dalam hal menarik minat konsumen. Apapun usaha yang dilakukan diharapkan mampu sesuai kepada tujuannya dan tetap pada koridor atau aturan Islam dan prinsip ekonomi. ${ }^{2}$ Karena tantangan usaha itu tidak hanya datang dari dalam perusahaan melainkan juga dari luar perusahaan seperti semakin tingginya persaingan yang ada, selera konsumen yang semakin beragam dan perkembangan teknologi yang semakin kompleks. ${ }^{3}$

Seiring dengan perkembangan ilmu pengetahuan dan teknologi yang semakin pesat, maka para wirausahawan dituntut untuk selalu melakukan pembelajaran dan evaluasi agar mampu bertahan menghadapi persaingan. Sebelum ditemukan Balanced Scorecard umumnya perusahaan akan menggunakan pendekatan tradisional yaitu menggunakan alat ukur secara terpisah seperti keuangan karena hanya bagian keuangan yang mudah diukur, dihitung dan dianalisis. Melalui Balanced Scorecard, semua kegiatan perusahaan dapat diukur, dianalisis, dan dievaluasi secara terintegrasi dangan cepat dan mudah. Balanced Scorecard adalah alat yang digunakan untuk mengukur kinerja perusahaan dengan memperhatikan konsep keuangan dan non keuangan antara jangka pendek dan jangka panjang serta melibatkan faktor internal dan eksternal. ${ }^{4}$

\section{B. Manajemen Pemasaran}

Manajemen merupakan bagian penting yang sekaligus membedakan manusia dengan mahluk hidup lainnya. Pandangan klasik tentang manajemen, pada umumnya dikatakan sebagai pranata yang dapat menjalankan tiga fungsi sekaligus. ${ }^{5}$ Pemasaran adalah suatu kegiatan usaha yang mengarahkan aliran barang dan jasa dari produsen kepada konsumen atau pemakai. Selama tahun 1960an titik berat dalam pemasaran beralih pada manajemen pemasaran. Sehingga pemasaran didefinisikan sebagai manajemen aliran barang dan jasa dari produsen ke konsumen. ${ }^{6}$

American Marketing Association (AMA) menawarkan definisi formal berikut: "Pemasaran adalah suatu fungsi organisasi dan serangkaian proses untuk menciptakan, mengomunikasikan, dan memberikan nilai kepada pelanggan dan untuk mengelola hubungan pelanggan dengan cara yang

\footnotetext{
${ }^{1}$ Nana Herdiana A, Manajemen Bisnis Syari'ah dan Kewirausahaan (Bandung : CV. Pustaka Setia ,2013), $239-240$.

${ }^{2}$ Ibid., 322.

${ }^{3}$ Kasmir dan Jakfar,Studi Kelayakan Bisnis,(Jakarta : Prenadamedia Group, 2016), 42.

${ }^{4}$ Freddy Rangkuti,SWOT Balanced Scorecard Teknik Menyusun Strategi Korporasi yang Efektif plus Cara Mengelola Kinerja dan Risiko(Jakarta: PT Gramedia Pustaka Utama,2011),.2.

5 Juliansyah Noor, Penelitian Ilmu Manajemen Tinjauan Filosofis dan Praktis Edisi Pertama,(Jakarta: Kencana Prenada Media Group,2013), 22.

${ }^{6}$ Basu Swastha, Azas-Azas Marketing,(Yogyakarta: Liberty Yogyakarta,2007), 7-8
} 
menguntungkan organisasi dan pemangku kepentingannya". 7 Didalam fungsi manajemen pemasaran ada kegiatan menganalisis yaitu analisis yang dilakukan untuk mengetahui pasar dan lingkungan pemasarannya, sehingga dapat diperoleh seberapa besar peluang untuk merebut pasar dan seberapa besar ancaman yang harus dihadapi. ${ }^{8}$ Definisi sosial menunjukkan peran yang dimainkan pemasaran di dalam masyarakat. Pemasaran adalah sebuah proses kemasyarakatan di mana individu dan kelompok memperoleh apa yang mereka butuhkan dan inginkan dengan menciptakan, menawarkan dan secara bebas mempertukarkan produk dan jasa yang bernilai dengan orang lain. ${ }^{9}$

Dalam konsep manajemen pemasaran yaitu berorientasi pada konsumen, perencanaan kegiatan pemasaran dan kepuasan konsumen. Perusahaan wajib menjalankan manajemen pemasaran dan melibatkan nya sebagai salah satu strategi penting untuk mencapai tujuan. Secara umum tujuan dari manajemen pemasaran diantaranya adalah untuk membangun permintaan, membangun kepuasan konsumen, mendapatkan penjualan, mendapatkan keuntungan, mendapatkan penciptaan sesuai harapan dan tentunya agar mendapatkan kelangsungan usahanya. ${ }^{10}$

Konsep dalam Manajemen Pemasaran Adalah Marketing sebagai sebuah disiplin ilmu pengetahuan yang meletakkan asumsi-asumsi dasar yang dapat digunakan dalam menciptakan nilai secara optimal bagi stakeholder dari waktu kewaktu. Oleh karena itu ketika perubahan nilai terjadi, maka konsep pemasaran pun akan berubah sesuai tuntutan pasar. Seorang pemilik usaha harus mampu mengidentifikasi kebutuhan dan keinginan pelanggan agar dapat memuaskan pelanggan dan menjaga pelanggan sebagai sarana untuk keberlanjutan usahanya. ${ }^{11}$

Dalam konsep pemasaran, ada beberapa aspek yang perlu diperhatikan seorang pengusaha dalam menjalankan usahanya, seperti :

a. Penawaran dan Merk

b. Nilai dan Kepuasan

c. Saluran Pemasaran

d. Rantai Pasokan

e. Persaingan

f. Lingkungan Pemasaran ${ }^{12}$

\section{Sistem Balanced Scorecard Sebagai Evaluasi Bisnis}

1. Sejarah Perkembangan Balanced Scorecard

Sejarah Balanced Scorecard dimulai dan diperkenalkan pada awal tahun 1990 di USA oleh David P Norton dan Robert Kaplan melalui suatu riset tentang "pengukuran kinerja dalam organisasi masa depan". ${ }^{13}$ Pengalaman menunjukkan bahwa pimpinan yang inovatif memakai BSC (Balanced Scorecard) tidak hanya untuk memperjelas dan mengomunikasikan strategi, tetapi juga untuk merencanakan dan mengembangkan strategi. Dengan demikian, BSC telah berkembang dari sebuah sistem pengukuran menjadi sebuah sistem manajemen. ${ }^{14}$

\section{Balanced Scorecard Sebagai Evaluasi Kinerja}

${ }^{7}$ Philip kotler dan Kevin Lane Keller, Manajemen Pemasaran Edisi 13 Jilid 1, ter.Bob Sabran (Jakarta : Erlangga,2009), 5.

${ }^{8}$ Agustina Shinta, Manajemen Pemasaran,(Malang : Universitas Brawijaya Press, 2011),.2.

9 Philip kotler dan Kevin Lane Keller, Manajemen Pemasaran Edisi 13 Jilid 1,ter.Bob Sabran (Jakarta : Erlangga,2009), h.5.

$10 \mathrm{https} / / /$ www.maxmanroe.com/vid/marketing/pengertian-manajemen-pemasaran.html diakses pada 20 okt 2018 pukul 08:37 WIB.

${ }^{11}$ Ali Hasan, Marketing dan Kasus-kasus Pilihan, (Yogyakarta:CAPS, 2014), h.4.

${ }^{12}$ Philip kotler dan kevin lane keller, Manajemen Pemasaran, h.12-15.

${ }^{13}$ Freddy Rangkuti,SWOT Balanced Scorecard,h,3.

${ }^{14}$ Robert S Kaplan dan David P Norton, Balanced Scorecard Menerapkan Strategi Menjadi Aksi ,ter.Peter R Yosi Pasla(Jakarta:Erlangga,2014),h.ix 
Sebelum ditemukan Balanced Scorecard biasanya perusahaan akan menggunakan pendekatan tradisional yaitu menggunakan alat ukur secara terpisah seperti keuangan karena hanya bagian keuangan yang mudah diukur ,dihitung dan dianalis. Melalui Balanced Scorecard, semua kegiatan perusahaan dapat diukur, dianalisis dan dievaluasi secara terintegrasi dangan cepat dan mudah. Sesungguhnya ada perspektif non keuangan yang lebih penting yang dapat digunakan dalam mengukur kinerja perusahaan. Kenyataan inilah yang menjadi awal terciptanya konsep Balanced Scorecard. ${ }^{15}$

Dengan semakin banyak BSC diterapkan di berbagai perusahaan, maka dapat dilihat bahwa kegunaannya sebagai berikut:

a. Mengklarifikasi dan menghasilkan konsensus mengenai strategi

b. Mengkomunikasikan strategi ke seluruh perusahaan

c. Menyelaraskan berbagai tujuan departemen dan pribadi dengan strategi perusahaan

d. Mengaitkan berbagai tujuan strategis dengan sasaran jangka panjang dan anggaran tahunan.

e. Mengidentifikasikan dan menyelaraskan berbagai inisiatif strategis

f. Melaksanakan peninjauan ulang strategis secara periodik dan sistematik

g. Mendapatkan umpan balik yang dibutuhkan untuk mempelajari dan memperbaiki strategi. ${ }^{16}$

3. Keunggulan Balanced Scorecard

Beberapa keunggulan utama sistem Balanced Scorecard dalam mendukung proses manajemen strategis antara lain:

a. Memotivasi personel untuk berpikir dan bertindak strategis. Untuk meningkatkan kinerja keuangan perusahaan, personel perlu menempuh langkah-langkah strategis dalam hal permodalan yang memerlukan langkah besar berjangka panjang. Selain itu sistem ini juga menuntut personel untuk mencari inisiatif-inisiatif strategis dalam mewujudkan sasaransasaran yang telah ditetapkan.

b. Menghasilkan progam kerja yang menyeluruh. Sistem BSC merumuskan sasaran strategis melalui keempat perspektif. Ketiga perspektif non keuangan hendaknya dipicu dari aspek keuangan.

c. Menghasilkan rencana bisnis yang terintegrasi. Sistem BSC dapat menghasilkan dua macam integrasi. Integrasi antara visi dan misi perusahaan dengan progam dan integrasi progam dengan rencana meningkatkan profit bersih. ${ }^{17}$

\section{Empat Perspektif Kinerja Bisnis dalam Balanced Scorecard}

\section{a. Perspektif Keuangan}

Ukuran finansial sangat penting dalam memberikan ringkasan konsekuensi tindakan ekonomis yang sudah diambil. Ukuran kinerja finansial memberikan petunjuk apakah strategi perusahaan, implementasi dan pelaksanannya memberikan kontribusi atau tidak kepada peningkatan laba perusahaan. Tujuan finansial biasanya berhubungan dengan profitabilitas melalui pengukuran laba operasi. Tujuan lainnya adalah pertumbuhan pendapatan yang cepat atau terciptanya arus kas yang positif. $^{18}$

Tujuan financial mugkin sangat berbeda untuk setiap tahap siklus hidup bisnis. Untuk menyederhanakannya, Kaplan dan Norton membaginya dalam 3 tahap yang masing-masing tahapnya mempunyai tujuan yang berbeda. ${ }^{19}$

\footnotetext{
${ }^{15}$ Freddy Rangkuti, SWOT Balanced Scorecard,h.3

${ }^{16}$ Kaplan dan norton, Balanced Scorecard, h.17.

${ }^{17}$ Freddy Rangkuti, SWOT Balanced Scorecard, h.94.

${ }^{18}$ Ibid.,h.75

${ }^{19}$ Kaplan dan Norton, Balanced Scorecard, h.42.
} 
1) Bertumbuh (Growth)

2) Bertahan (Sustain)

3) Menuai (Harvest) ${ }^{20}$

Berdasarkan metode yang digunakan dalam BSC, kinerja pada perspektif keuangan diukur dengan menggunakan ukuran laba investasi, peningkatan penjualan, bauran pendapatan, pemanfaatan aktiva, efisiensi biaya. ${ }^{21}$ Dengan sasaran strategis :

a. Meningkatkan pertumbuhan pelanggan

b. Meningkatkan penggunaan asset

c. Meningkatkan produktivitas

d. Mengurangi biaya ${ }^{22}$

\section{b. Perspektif Pelanggan}

Dalam perspektif pelanggan BSC, manajemen harus dapat mengidentifikasi pelanggan dan segmen pasar dimana unit bisnis tersebut akan bersaing dan berbagai ukuran kinerja unit bisnis di dalam segmen sasaran. Kinerja pada perspektif pelanggan diukur melalui:

1) Jumlah pelanggan baru

2) Jumlah pelanggan yang membeli kembali

3) Loyalitas pelanggan

Ukuran dari perspektif pelanggan akan terlihat dari pencapaian (pangsa pasar), kemampuan mempertahankan pelanggan, kemampuan meningkatkan jumlah pelanggan loyal, tingkat kepuasan pelanggan dan tingkat profitabilitas pelanggan. ${ }^{23}$

Nilai kepuasan dan loyalitas konsumen ditentukan oleh nilai yang diterima pelanggan. Semakintinggi nilai yang diterima pelanggan, semakin tinggi pula tingkat kepuasan dan akhirnya pelanggan akan semakin loyal. Pemasar dapat meningkatkan penawaran dengan menaikkan kombinasi manfaat fungsional, psikis ataupun emosional, sementara pelanggan mendapat manfaat dari transaksi yang terjadi dan mengendalikan sepenuhnya biaya yang akan dikeluarkan ${ }^{24}$

Perspektif pelanggan juga memungkinkan perusahaan melakukan identifikasi dan pengukuran, secara eksplisit proposisi nilai yang akan perusahaan berikan kepada pelanggan dan pasar sasaran. Perusahaan masa lalu memusatkan diri pada kapabilitas internal, dengan mengandalkan kinerja produk dan inovasi teknologi. Tanpa memahami kebutuhan konsumen yang akhirnya tidak bisa menjamin kelangsungan usahanya karena persaingan yang tinggi. ${ }^{25}$

\section{c. Perspektif Internal Bisnis}

Dalam perspektif proses bisnis internal, para penanggung jawab mengidentifikasi berbagai proses internal penting yang harus dikuasai baik oleh perusahaan. Proses ini memungkinkan unit bisnis untuk:

1) Memberikan preposisi nilai yang akan menarik perhatian dan mempertahankan pelanggan dalam segmen pasar sasaran

2) Memenuhi harapan keuntungan finansial kepada para pemegang saham ${ }^{26}$

3) Setiap bisnis memiliki rangkaian proses tertentu untuk menciptakan nilai bagi pelanggan dan memberikan hasil financial yang baik.

\footnotetext{
${ }^{20}$ Ibid.,h.43.

${ }^{21}$ Freddy, SWOT, h.5

${ }^{22}$ Ibid., h. 85.

${ }^{23}$ Ibid., h.76.

${ }^{24}$ Nana Herdiana, Manajemen Strategi Pemasaran, h. 428

${ }^{25}$ Kaplan dan Norton, Balanced Scorecard,h,55.

${ }^{26}$ Freddy Rangkuti, SWOT Balanced Scorecard, h.76
} 
Pada bagian pemasaran terdapat indikator yang dipakai dalam menentukan tolak ukur bagi kinerja proses bisnis internal perusahaan. Proses mengidentifikasikan bisnis internal terdiri dari 3 tahap:

a) Inovasi

Tuntutan terhadap inovasi dalam bisnis merupakan hal yang sangat penting agar perusahaan atau produk tetap menjadi pilihan para pelanggan. Inovasi dalam bisnis didukung oleh adanya tranfer informasi antar manajer dan pembeli, perusahaan berorientasi pada pasar, serta didukung oleh kemampuan menggunakan informasi dalam proses inovasi. ${ }^{27}$

Dalam proses inovasi, unit bisnis meneliti kebutuhan pelanggan yang sedang berkembang atau yang masih tersembunyi dan kemudian menciptakan produk atau jasa yang akan memenuhi kebutuhan tersebut. Proses inovasi terdiri atas dua komponen. Dalam komponen yang pertama para manajer melaksanakan penelitian pasar untuk mengenali ukuran pasar, bentuk preferensi pasar, bentuk preferensi pelanggan, dan tingkat harga produk dan jasa sasaran. Ketika perusahaan melaksanakan proses internal untuk memenuhi kebutuhan pelanggan tertentu, memiliki informasi yang akurat dan dapat diandalkan tentang ukuran pasar dan preferensi pelanggan menjadi tugas penting yang harus dilaksanakan dengan baik. ${ }^{28}$

\section{b) Operasi}

Proses operasi merupakan proses dimana produk dan jasa disampaikan kepada pelanggan. Dimulai dari diterimanya pesanan pelanggan dan diakhiri dengan penyampaian produk atau jasa kepada pelanggan. Proses ini menitikberatkan kepada penyampaian produk atau jasa kepada pelanggan yang ada secara efisien, konsisten, dan tepat waktu.

c) Layanan purna jual

Layanan purna jual adalah nilai terakhir dari rantai internal. Layanan purna jual mencakup garansi dan berbagai aktivitas perbaikan, penggantian produk yang rusak dan yang dikembalikan, serta proses pembayaran, seperti administrasi kartu kredit. ${ }^{29}$

\section{d. Perspektif Pembelajaran dan Pertumbuhan}

Perspektif pembelajaran dan pertumbuhan mengidentifikasi infrastruktur yang harus dibangun dalam menciptakan pertumbuhan dan peningkatan kinerja jangka panjang. Sumber utama pembelajaran dan pertumbuhan perusahaan adalah manusia, sistem, dan prosedur. Untuk mencapai tujuan perspektif finansial, pelanggan dan proses bisnis internal, perusahaan harus melakukan investasi dengan memberikan pelatihan kepada pengurusnya, meningkatkan teknologi dan sistem informasi, serta menyelaraskan berbagai prosedur dan kegiatan operasional yang merupakan sumber utama perspektif pembelajaran dan pertumbuhan. ${ }^{30}$ Menurut Kaplan dan Norton, dalam membangun BSC di berbagai perusahaan jasa dan manufaktur telah mengungkapkan tiga kategori utama untuk perspektif pembelajaran dan pertumbuhan. ${ }^{31}$

\section{1) Kapabilitas Pekerja}

Dewasa ini tenaga kerja pada perusahaan lebih dituntut untuk dapat berpikir kritis dan melakukan evaluasi terhadap proses dan lingkungan untuk dapat memberikan usulan perbaikan. Oleh sebab itu, dalam pengukuran strategi perusahaan, salah satunya harus berkaitan secara spesifik dengan kemampuan pegawai, yaitu apakah perusahaan telah merencanakan peningkatan

\footnotetext{
27 Ali Hasan, Marketing, h.304.

${ }^{28}$ Kaplan dan Norton, Balanced Scorecard, h. 85.

${ }^{29}$ Ibid.,h.90-92

${ }^{30}$ Freddy , SWOT Balanced Scorecard, h.77

${ }^{31}$ Kaplan dan Norton, Balanced Scorecard, h,109-118.
} 
kemampuan sumber daya manusia yang dimiliki. Dalam kaitan dengan sumber daya manusia ada tiga hal yang perlu ditinjau dalam menerapkan BSC, yaitu:

a) Kepuasan pekerja

Tujuan kepuasan pekerja menyatakan bahwa moral pekerja dan kepuasan kerja secara keseluruhan saat ini dipandang sangat penting oleh sebagian besar perusahaan. Pekerja yang puas merupakan pra kondisi bagi meningkatnya produktivitas, daya tanggap, mutu dan layanan pelanggan.Perusahaan yang ingin mencapai tingkat kepuasan pelanggan yang tinggi perlu memiliki pelanggan yang dilayani oleh pekerja yang terpuaskan oleh perusahaan.

b) Retensi pekerja

Tujuan dari retensi pekerja adalah untuk mempertahankan pekerja-pekerja terbaik pada perusahaan. Perusahaan yang membuat investasi jangka panjang dalam diri para pekerja sehingga setiap kali ada pekerja berhenti yang bukan atas keinginan perusahaan merupakan suatu kerugian modal intelektual bagi perusahaan. Para pekerja yang loyal membawa nilai perusahaan, pengetahuan tentang berbagai proses organisasional, dan diharapkan sensitivitasnya terhadap kebutuhan pelanggan. Umumnya diukur dengan presentase keluarnya pekerja yang memegang jabatan kuncil

\section{c) Produktivitas pekerja}

Produktivitas pekerja adalah suatu ukuran hasil, dampak keseluruhan usaha peninggalan moral dan keahlian pekerja, inovasi, proses internal, dan kepuasan pelanggan. Tujuannya adalah membandingkan keluaran yang dihasilkan terhadap jumlah keseluruhan pekerja.

\section{2) Kapabilitas sistem informasi}

Untuk menunjang pencapaian tujuan proses pembelajran dan pertumbuhan jika mengandalkan motivasi dan keterampilan karyawan saja tidak cukup apabila mereka tidak mempunyai informasi yang cukup. Oleh sebab itulah, karyawan membutuhkan banyak informasi mengenai pelanggan, proses internal dan konsekuensi financial keputusan perusahaan. Para pekerja garis depan perlu mendapatkan informasi yang akurat dan tepat waktu tentang setiap hubungan yang ada antara perusahaan dengan pelanggan.

\section{3) Motivasi, Pemberdayaan dan keselarasan}

Kontribusi usaha yang dilakukan pegawai harus dimotivasi dengan tujuan perusahaan. Tolak ukur yang digunakan antara lain jumlah masukan yan diberikan kepada perusahaan dan penerapannya, jumlah perbaikan, keseimbangan individu dan perusahaan, kinerja team work dan pribadi. $^{32}$

Dalam perspektif pertumbuhan dan pembelajaran ini terdapat indikator yang mengutamakan kemampuan karyawan dalam mengolah bahan baku menjadi bahan jadi. Pembinaan karyawan menjadi hal yang penting yang harus diusahakan oleh perusahaan agar karyawan bekerja dengan produktif dan maksimal. Pemenuhan kepuasan pegawai menjadi tanggung jawab perusahaan yang harus dicapai. Salah satunya dengan pemenuhan gaji yang sesuai dan tepat waktu. Telah banyak kita mendengar hadist yang mengungkapkan:

\footnotetext{
${ }^{32}$ Kaplan dan Norton, Balanced Scorecard, h,109-118.
} 


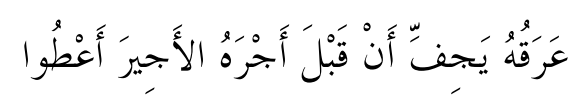

“Berikanlah pekerja upahnya sebelum keringatnya kering” (HR. Ibnu Majah). ${ }^{33}$

Hadist ini menjelaskan bahwa dalam islam telah menganjurkan agar memberikan upah atau hak pekerja setelah dia menyelesaikan kewajibannya dengan segera. Karena menunda memberikan gaji kepada pegawai bagi majikan yang mampu adalah perbuatan dzolim.

${ }^{33}$ https://muslim.or.id/22973-bayarkan-gaji-pegawaimu-sebelum-keringatnya-kering.html diakses pada tanggal 20 Desember 2018 pukul 19.30 wib. 


\section{PENUTUP}

Seorang pebisnis akan selalu berusaha memberikan pelayanan yang terbaik (prima) kepada mitra bisnisnya. Pelayanan terbaik (prima) tentunya tidak bertentangan dengan prinsip syari'ah (Islam), seperti suap, menipu, serta praktik-praktik bisnis yang tidak bermoral. Apapun usaha yang dilakukan diharapkan mampu sesuai kepada tujuannya dan tetap pada koridor atau aturan Islam dan prinsip ekonomi. Karena tantangan usaha itu tidak hanya datang dari dalam perusahaan melainkan juga dari luar perusahaan seperti semakin tingginya persaingan yang ada, selera konsumen yang semakin beragam dan perkembangan teknologi yang semakin kompleks. Seiring dengan perkembangan ilmu pengetahuan dan teknologi yang semakin pesat, maka para wirausahawan dituntut untuk selalu melakukan pembelajaran dan evaluasi agar mampu bertahan menghadapi persaingan. Sebelum ditemukan Balanced Scorecard umumnya perusahaan akan menggunakan pendekatan tradisional yaitu menggunakan alat ukur secara terpisah seperti keuangan karena hanya bagian keuangan yang mudah diukur, dihitung dan dianalisis. Melalui Balanced Scorecard, semua kegiatan perusahaan dapat diukur, dianalisis, dan dievaluasi secara terintegrasi dangan cepat dan mudah.

\section{DAFTAR PUSTAKA}

Hasan, Ali. 2014. Marketing dan Kasus-kasus Pilihan. Yogyakarta: CAPS.

Herdiana A, Nana. 2013. Manajemen Bisnis Syari'ah dan Kewirausahaan. Bandung : CV. Pustaka Setia.

Kasmir dan Jakfar. 2016. Studi Kelayakan Bisnis. Jakarta : Prenadamedia Group.

Noor, Juliansyah. 2013. Penelitian Ilmu Manajemen Tinjauan Filosofis dan Praktis Edisi Pertama. Jakarta: Kencana Prenada Media Group.

Philip kotler dan Kevin Lane Keller. 2009. Manajemen Pemasaran Edisi 13 Jilid 1 ter.Bob Sabran. Jakarta : Erlangga.

Rangkuti, Fredy. 2011. SWOT Balanced Scorecard Teknik Menyusun Strategi Korporasi yang Efektif plus Cara Mengelola Kinerja dan Risiko. Jakarta: PT Gramedia Pustaka Utama.

Robert S Kaplan dan David P Norton, 2014. Balanced Scorecard Menerapkan Strategi Menjadi Aksi ,ter.Peter R Yosi Pasla. Jakarta: Erlangga.

Shinta, Agustina. 2011. Manajemen Pemasaran. Malang: Universitas Brawijaya Press.

Swastha, Basu. 2007. Azas-Azas Marketing. Yogyakarta: Liberty Yogyakarta.

https://muslim.or.id/22973-bayarkan-gaji-pegawaimu-sebelum-keringatnya-kering.html diakses pada tanggal 20 Desember 2018 pukul 19.30 wib.

https://www.maxmanroe.com/vid/marketing/pengertian-manajemen-pemasaran.html diakses pada 20 okt 2018 pukul 08:37 WIB. 
